\title{
Interplay between cell adhesion and growth factor receptors: from the plasma membrane to the endosomes
}

\author{
Johanna Ivaska • Jyrki Heino
}

Received: 11 June 2009 / Accepted: 3 August 2009 / Published online: 1 September 2009

(C) The Author(s) 2009. This article is published with open access at Springerlink.com

\begin{abstract}
The emergence of multicellular animals could only take place once evolution had produced molecular mechanisms for cell adhesion and communication. Today, all metazoans express integrin-type adhesion receptors and receptors for growth factors. Integrins recognize extracellular matrix proteins and respective receptors on other cells and, following ligand binding, can activate the same cellular signaling pathways that are regulated by growth factor receptors. Recent reports have indicated that the two receptor systems also collaborate in many other ways. Here, we review the present information concerning the role of integrins as assisting growth factor receptors and the interplay between the receptors in cell signaling and in the orchestration of receptor recycling.
\end{abstract}

Keywords Integrin - Cell adhesion · Growth factor .

Signaling $\cdot$ Endocytosis

\section{Integrin family of adhesion receptors}

The integrin family of cell adhesion receptors mediates the anchoring of cell to the protein fibrils and networks that

J. Ivaska

VTT Technical Research Centre of Finland,

Medical Biotechnology,

Turku FI-20520, Finland

J. Ivaska

Centre for Biotechnology, Turku University,

Turku FI-20520, Finland

J. Ivaska $\cdot$ J. Heino $(\triangle)$

Department of Biochemistry and Food Chemistry,

University of Turku,

Turku FI-20014, Finland

e-mail: jyrki.heino@utu.fi compose the extracellular matrix (ECM). In addition, certain members of the integrin family can bind to plasma proteins or respective receptors on other cells. Based on their structure and phylogeny, human integrin $\alpha$ subunits can be divided into four categories (Johnson et al. 2009). Basically, all metazoans seem to have integrins that recognize arginine-glycine-aspartic acid (RGD) motifs in their ligands. In vertebrates, they act as receptors for ECM glycoproteins, such as fibronectin, vitronectin, and fibrinogen. The classical fibronectin receptor, $\alpha 5 \beta 1$ integrin, plays an important role during development, since mice lacking $\alpha 5 \beta 1$ die early during embryonic development (Yang et al. 1993). Integrin $\alpha 8 \beta 1$ is another fibronectin receptor and is important for the development of the kidney (Muller et al. 1997) and inner ear (Littlewood Evans and Muller 2000). Platelet fibrinogen receptor, $\alpha \mathrm{IIb} \beta 3$ integrin, is important for hemostasis, whereas the physiological role of the five $\alpha \mathrm{V}$-containing heterodimers $(\alpha \mathrm{V} \beta 1, \alpha \mathrm{V} \beta 3, \alpha \mathrm{V} \beta 5$, $\alpha \mathrm{V} \beta 6, \alpha \mathrm{V} \beta 8)$ is less obvious. Deficiency of all five receptors in $\alpha \mathrm{V}$-null animals causes a surprisingly mild phenotype (Bader et al. 1998). The development of most organs is close to normal, and some of the animals may be born alive, although they die soon after birth because of defects in their blood vessels (Bader et al. 1998). The deficiency of $\alpha \mathrm{V} \beta 8$ integrin has been show to affect brain vessel formation (Zhu et al. 2002). However, in general, the role of $\alpha \mathrm{V}$ integrins in angiogenesis has been under debate since inhibitors of $\alpha \mathrm{V}$ function can block angiogenesis in animal models (Brooks et al. 1994), whereas the genetic deletion of $\alpha \mathrm{V} \beta 3$ and $\alpha \mathrm{V} \beta 5$ integrins actually promotes angiogenesis (Reynolds et al. 2002). Furthermore, small concentrations of RDG-mimetic integrin inhibitors may also promote angiogenesis (Reynolds et al. 2009).

Laminin receptor integrins are also widespread in the animal kingdom suggesting their early evolution. Integrin 
$\alpha 3 \beta 1$ appears to be important for the normal development of the lung, kidney (Kreidberg et al. 1996), and skin (DiPersio et al. 1997), whereas $\alpha 6 \beta 4$ integrin is an essential component of hemidesmosomes (Dowling et al. 1996). Integrin $\beta 4$ is exceptional when compared with all other integrins because of its large intracellular part. In addition to $\beta 4, \alpha 6$ can have another $\beta$ partner, namely $\beta 1$ integrin. $\alpha 7 \beta 1$ is specific to muscles and, when genetically defective, causes a type of muscular dystrophy in mice (Mayer et al. 1997), whereas $\alpha 7$ mutations may lead to congenital myopathy in man (Hayashi et al. 1998).

Integrins $\alpha 4$ and $\alpha 9$ can both form a heterodimer with $\beta 1$ integrin. In addition, $\alpha 4$ can have another $\beta$ partner, namely $\beta 7$. Based on their structural features, the two $\alpha$ subunits are considered to form a separate subgroup of integrins (Johnson et al. 2009). Integrin $\alpha 4$ can bind to fibronectin in ECM in an RGD-independent manner. It can also mediate cell-cell interaction and act as a receptor for VCAM (vascular cell adhesion molecule), which is a transmembrane protein belonging to the immunoglobulin superfamily. Integrin $\alpha 4$ is important for early steps of embryonic development, and its deficiency causes embryonic lethality (Yang et al. 1995). Integrin $\alpha 9 \beta 1$ has several ECM ligands, including tenascin C. Functionally, $\alpha 9 \beta 1$ integrin has been associated with the regulation of lymphangiogenesis (Huang et al. 2000).

The fourth phylogenic subgroup of integrin $\alpha$ subunits is composed of members that differ from all other integrin subunits based on the finding that they contain an extra domain in their structure. After the cloning of the integrin $\alpha$ subunits, the extra domain was named an I domain, i.e., an inserted domain. Later, the $\alpha \mathrm{I}$ domain was realized to be the ligand-binding domain in this subset of integrins. The integrin $\alpha \mathrm{I}$ domain takes a Rossmann fold and, therefore, is similar to the von Willebrand factor A domain (Michishita et al. 1993). Based on this finding, integrin I domains are also called integrin A domains. The $\alpha \mathrm{I}$ domain integrins are only found in chordates (Johnson et al. 2009). In vertebrates, the $\alpha$ I domain integrins can be further divided into two functionally different subgroups, namely the leukocyte integrins $(\alpha \mathrm{D} \beta 2, \alpha \mathrm{E} \beta 7, \alpha \mathrm{L} \beta 2, \alpha \mathrm{M} \beta 2$, and $\alpha \mathrm{X} \beta 2$; for a review, see Evans et al. 2009) and the collagen receptor integrins $(\alpha 1 \beta 1, \alpha 2 \beta 1, \alpha 10 \beta 1$, and $\alpha 11 \beta 1$; for a review, see Heino 2007). These integrins seem to have specialized functions related to, amongst others, native and acquired immunity, thrombosis, and the development of connective tissues.

Integrins anchor cells to the ECM and have an important role in the maintenance of tissue integrity. However, integrins are also signaling receptors (for a review, see Legate et al. 2009). Unlike many growth factor receptors, integrins have no enzymatic activity, and their signaling function is dependent on their binding to intracellular proteins. Integrin heterodimers may take alternative conformations in which the integrin cytoplasmic domains are either together or separated from each other (for a review, see Arnaout et al. 2007; Luo et al. 2007). Recent studies have stressed the flexibility of the integrin structure and suggest that integrins can have many different conformations and activation states (Zhu et al. 2008). The cytoplasmic domains of the integrin $\beta$ subunits alone have been reported to bind to tens of different cytoskeletal and signaling proteins (for a review, see Legate and Fassler 2009). The interactions of integrin $\alpha$ subunits with intracellular proteins are much less studied, but $\alpha$ subunits are nevertheless thought to play an important part in heterodimer-specific signaling events. Given the finding that the intracellular domains are relatively short, only a limited number of proteins can bind at any one time. Therefore, integrins can probably gather various types of protein complexes.

Talin is an actin-binding protein that can also recognize a specific motif in the cytoplasmic domains of integrin $\beta$ subunits. Talin has been found to be an important activator of integrin-ligand-binding function (Tadokoro et al. 2003). Its binding to the tail of $\beta$ subunit breaks a salt bridge between $\alpha$ and $\beta$ subunits and induces a conformational change leading to the extension of the integrin ectodomain, whereas the inactive integrin is considered to be bent. Kindlins $1-3$ bind to a distinct motif in $\beta$ cytoplasmic domain when compared with talin (Moser et al. 2009). Kindlins act together with talin in the regulation of integrin activity (Moser et al. 2009). Other proteins binding to $\beta$ cytoplasmic domains include the protein tyrosine kinases, such as focal adhesion kinase, Src, and integrin-linked kinase. These kinases and numerous other kinases, phosphatases, GTP-ases, and adaptor proteins can link the integrins to downstream signaling pathways (Legate et al. 2009).

Because of its large cytoplasmic domain, $\beta 4$ integrin is considered to behave in a different manner from all other integrin $\beta$ subunits. Tyrosine kinases, such as Src family kinases, can phosphorylate the cytoplasmic domain $\beta 4$ and create a binding site for Shc that further activates Ras and its downstream signaling pathways (Mainiero et al. 1997; Shaw et al. 1997).

\section{Direct binding of integrins to growth factors}

Integrins are known to regulate the same signaling pathways as growth factor receptors (Fig. 1). A classic example of this is the ability of a subset of integrins to engage ligands and subsequently activate the Shc-Ras-Mitogenactivated protein kinase pathway in a manner similar to growth factor receptors (Wary et al. 1996, 1998). More recently, we have realized that some integrins may also 


\section{a Activation of latent growth factor}
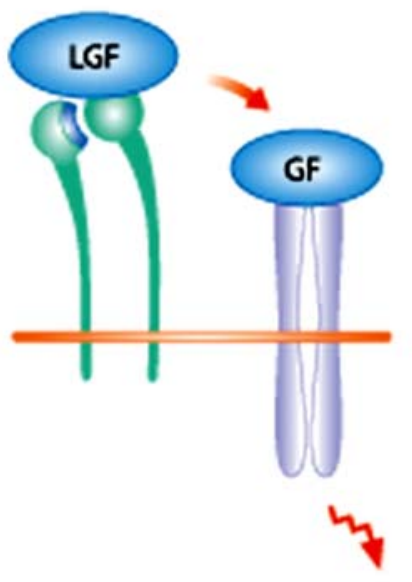

d Collaborative activation
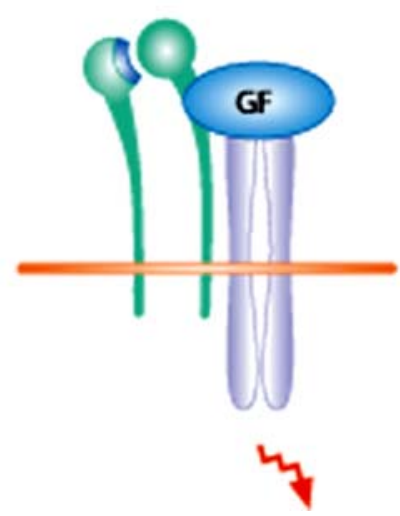

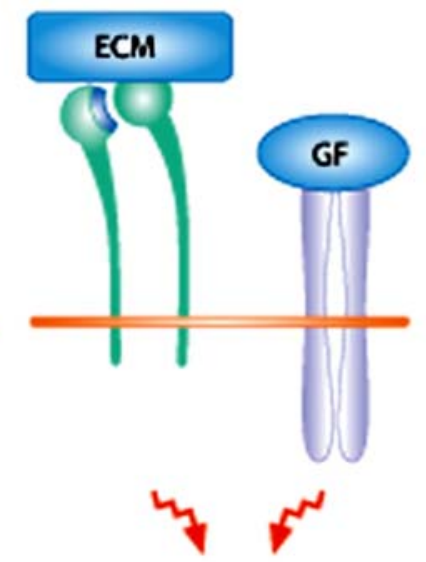

b Regulation of common signaling pathways

e Direct activation

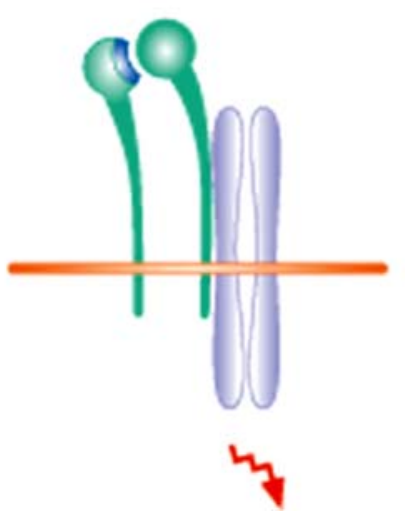

Fig. 1 Various forms of collaboration between integrins (green) and growth factor receptors (blue). a Integrins may directly bind to latent growth factors $(L G F)$ and activate them. Subsequently, activation growth factors $(G F)$ can bind to their signaling receptors. b The binding of integrins to extracellular matrix $(E C M)$ proteins often activates the same signaling pathways as GF binding to GF receptors. c Receptors can signal when located either on the cell surface or in endosomes. Co-endocytosis of integrins and GF receptors regulates cellular signaling at multiple levels. d, e Integrins

bind directly to growth factors (Fig. 1). The best-known example is $\alpha \mathrm{V} \beta 6$ integrin, which plays a crucial role in the activation of transforming growth factor- $\beta$ (TGF- $\beta$ ). The latency-associated peptide (LAP) in latent TGF- $\beta$ (LTGF$\beta)$ has an RGD motif that can be recognized by $\alpha \mathrm{V} \beta 6$ integrin. The binding of LTGF- $\beta$ to $\alpha \mathrm{V} \beta 6$ integrin leads to the activation of the growth factor (Munger et al. 1999). In addition, LTGF- $\beta$ can be activated by plasmin (Sato and Rifkin 1989), by metalloproteinases (Yu and Stamenkovic 2000), or by binding to thrombospondin (Crawford et al.

\section{Regulation of entry and recycling}

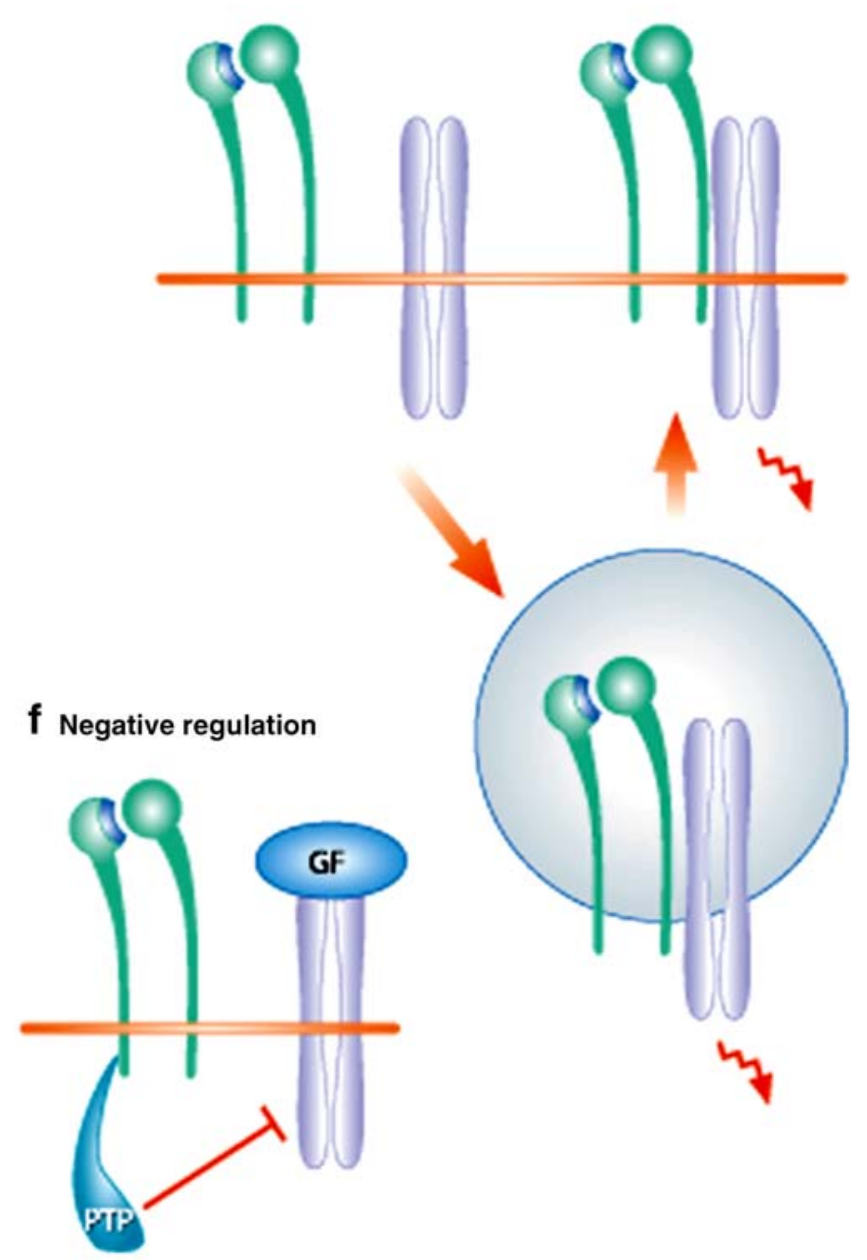

can activate GF receptors in a collaborative or direct manner. In both cases, integrins create an environment in which the GF receptors can properly interact with the downstream signaling molecules. In the collaborative mechanism, the binding of GFs to their receptors precedes receptor activation (d), whereas in the direct mechanism, the GF receptors are activated without ligand binding (e). f Integrins can also activate protein tyrosine phosphatases $(P T P)$ and suppress signaling by GF receptors

1998). Despite the finding that the $\alpha \mathrm{V} \beta 6$-mediated activation of LTGF- $\beta$ represents only one of many alternative activation mechanisms, $\alpha \mathrm{V} \beta 6$ seems to be critical for TGF$\beta$ action in many animal models for fibrotic diseases. The lack of $\beta 6$ integrin makes mice resistant to pulmonary fibrosis induced by bleomysin (Munger et al. 1999), and to kidney (Ma et al. 2003) and biliary (Wang et al. 2007) fibrosis. On the other hand, the overexpression of $\beta 6$ integrin in mouse skin induces the spontaneous formation of chronic wounds (Hakkinen et al. 2004). Integrin $\alpha \mathrm{V} \beta 8$ 
can also bind to LTGF- $\beta$ and activate the growth factor. The activation mechanism is reported to involve a membrane-type matrix metalloproteinase, MT1-MMP (Mu et al. 2002). Integrin $\alpha V \beta 8$ is expressed on brain astrocytes and is considered to mediate cross-talk with $\alpha \mathrm{V} \beta 8$-negative endothelial cells in a TGF- $\beta$-dependent manner (Cambier et al. 2005). The finding that $\alpha \mathrm{V} \beta 8$ integrin-deficient mice have lethal defects in the development of the blood vessels in the brain (Zhu et al. 2002) further stresses the physiological importance of this mechanism. LTGF- $\beta$ might also be recognized by $\alpha \mathrm{V} \beta 1, \alpha \mathrm{V} \beta 5$ (Munger et al. 1998), $\alpha \mathrm{V} \beta 3$ (Asano et al. 2005), and $\alpha 8 \beta 1$ ( $\mathrm{Lu}$ et al. 2002). However, the physiological relevance of these interactions is not clear. For example, integrin $\alpha \mathrm{V} \beta 1$ is abundantly expressed in various cell lines, but its existence in tissues is uncertain.

In addition to LTGF- $\beta$, integrins can also bind to other growth factors that regulate angiogenesis and lymphangiogenesis. Integrin $\alpha 9 \beta 1$ can bind to vascular endothelial growth factors A, C, and D (VEGF-A, -C, -D; Vlahakis et al. 2005, 2007). The role of $\alpha 9 \beta 1$ seems to be critical especially during lymphangiogenesis, since the lack of $\alpha 9 \beta 1$ in the mouse prevents lymphangiogenesis (Huang et al. 2000). VEGF-A can also be recognized by $\alpha 3 \beta 1$ and $\alpha \mathrm{V} \beta 3$ integrins (Hutchings et al. 2003). However, these integrins can only bind to the $165-\mathrm{kDa}$ splicing varant of VEGF-A, whereas $\alpha 9 \beta 1$ can also recognize the $121-\mathrm{kDa}$ variant (Vlahakis et al. 2005). Integrin binding to VEGF-A seems to regulate endothelial cell migration, and results from in vivo assays, such as the chick chorioallantoic membrane assay, indicate that the interaction is relevant for angiogenesis (Vlahakis et al. 2007). In addition to VEGFs, angiopoietins, such as angiopoietin-1 and -2, form a further group of growth factors required for angiogenesis. Integrin $\alpha 5 \beta 1$ has been shown to recognize angiopoietin- 1 and -2 proteins (Carlson et al. 2001), but the in vivo role of this interaction is unclear.

Growth factors that can act as direct ligands for integrins also include fibroblast growth factor-1 (FGF-1), nerve growth factor (NGF), and two other neurotrophins. Integrin $\alpha \mathrm{V} \beta 3$ has been shown to be a receptor for FGF-1 and to modulate FGF-1 signaling through its tyrosine kinase receptor (Mori et al. 2008). NGF, brain-derived neurotrophic factor, and NT3 are ligands for $\alpha 9 \beta 1$ integrin. Integrin-NGF interaction stimulates cell proliferation and migration. In addition to modulating the signaling by NGF receptor TrkA/NTRK1, NGF binding to $\alpha 9 \beta 1$ may activate integrin signaling (Staniszewska et al. 2008).

Semaphorin 7A (Sema7A, CD108) is known to regulate axon outgrowth through $\beta 1$-integrin receptors and to contribute to the formation of the lateral olfactory tract. Sema7A is also expressed on activated $\mathrm{T}$ cells and stimulates cytokine production in monocytes and macro- phages through $\alpha 1 \beta 1$ integrin (Suzuki et al. 2007). This function of Sema7A has been reported to be based on the ability of Sema7A to act as a direct ligand for $\alpha 1 \beta 1$ integrin (Suzuki et al. 2007).

The biological consequences of growth factor binding to an integrin seem to be variable (Table 1). In the case of LTGF- $\beta$, the obvious role of the integrin is to activate the latent growth factor by inducing a conformational change or presenting the latent growth factor to a protease. Integrins may also assist the binding of a growth factor to its receptor, or the growth factor may even activate integrin signaling. In many experiments, cells have been allowed to attach to cell culture wells that have been precoated with growth factors. Under these conditions, the cells can adhere and migrate. However, whether integrin can take advantage of growth factors in the same manner under in vivo conditions remains unclear.

\section{Integrins and growth factor receptors}

Integrins and growth factor receptors are known to regulate the same signaling pathways, and together they regulate cell differentiation, proliferation, and survival. The balance of the various activating and inhibiting signals is considered to determine cell fate. However, the interplay between integrins and growth factor receptors is more complex than the simple independent activation of the same signaling pathways (Fig. 1). The binding of integrins to their ligands can cause the formation of large integrin clusters (Kim et al. 2004; Miyamoto et al. 1995). In some experimental models, inside-out integrin activation has also induced the lateral movement of ligand-free integrins on the cell surface and the formation of similar clusters (Cambi et al. 2006; Connors et al. 2007). Clustered integrins also seem to bunch together other surface receptors, including growth factor receptors (Yamada and Even-Ram 2002). Moreover, integrins seem to have a regulatory role in the activation of growth factor receptors. Integrin-dependent activation of growth factor receptors in these clusters can be either direct or collaborative (Yamada and Even-Ram 2002). In the collaborative mechanism, the binding of growth factors to the growth factor receptors precedes receptor activation, whereas the role of the integrins is to create an environment in which the growth factor receptors can properly interact with the downstream signaling molecules (Fig. 1). In the direct mechanism, the integrin-mediated aggregation of growth factor receptors induces the formation of clusters in which the growth factor receptors are able, for example, to phosphorylate each other. Thus, the presence of the growth factors is not needed in the direct mechanism (Fig. 1).

One of the physiologically most relevant examples of collaboration between integrins and growth factors is 
Table 1 Direct binding of integrins to growth factors ( $V E G F$ vascular endothelial growth factor, $N G F$ nerve growth factor, $F G F$ fibroblast growth factor, $N T$ neurotrophin)

\begin{tabular}{llll}
\hline Integrin & Growth factor & Physiological role & Reference \\
\hline$\alpha 1 \beta 1$ & Semaphorin 7A & Inflammation & Suzuki et al. 2007 \\
$\alpha 3 \beta 1$ & VEGF-A (165) & Angiogenesis & Hutchings et al. 2003 \\
$\alpha 5 \beta 1$ & Angiopoietin-1 & Angiogenesis & Carlson et al. 2001 \\
& Angiopoietin-2 & Angiogenesis & Carlson et al. 2001 \\
$\alpha 9 \beta 1$ & VEGF-A (121, 165) & Angiogenesis & Vlahakis et al. 2007 \\
& VEGF-C, VEGF-D & Lymphangiogenesis & Vlahakis et al. 2005 \\
& NGF & Cell proliferation & Staniszewska et al. 2008 \\
& Brain-derived neurotrophic factor & & Staniszewska et al. 2008 \\
& NT3 & & Staniszewska et al. 2008 \\
$\alpha \mathrm{V} \beta 3$ & FGF-1 & FGF signaling & Mori et al. 2008 \\
& VEGF-A (165) & Angiogenesis & Hutchings et al. 2003 \\
$\alpha \mathrm{V} \beta 6$ & LTGF- $\beta$ & TGF- $\beta$ activation. & Munger et al. 1999 \\
& LTGF- $\beta$ & Fibrosis and inflammation & Cambier et al. 2005 \\
\hline
\end{tabular}

adhesion-dependent survival. Adherent cells are widely known to depend on integrin-mediated adhesion for responsiveness to growth factors. Loss of adhesion in normal cells results in growth arrest or anoikis (detachment induced apoptosis) attributable to impaired signaling induced by growth factors and cytokines (Danen and Yamada 2001; Frisch and Francis 1994; Schwartz and Assoian 2001). The mechanisms supporting permissive signals from integrins in normal cells seem to vary depending on the cell type and are not fully understood. However, the described mechanisms include the loss of PI3K-Akt pathway signaling, focal adhesion kinase inactivation, the activation of Jun N-terminal kinase, and the phosphatase-induced inactivation of protein kinase $C_{\varepsilon}$ (Frisch and Ruoslahti 1997; Ivaska et al. 2003; Ruoslahti 1999). Further insight into the co-operation between adhesion and survival has come from studies in cancer cells. Resistance to anoikis is emerging as a hallmark of metastatic malignancies (Liotta and Kohn 2004), and many different mechanisms have been described to regulate the escape from anoikis. These mechanisms are similar to those seen in drug resistance and include the upregulation of kinases (Douma et al. 2004) and scaffolding molecules (Parsons et al. 2009), the suppression of apoptotic pathways (Simpson et al. 2008), and, recently, the hypoxia-induced inhibition of receptor tyrosine kinase (RTK) endocytosis (Wang et al. 2009) and the downregulation of $\alpha 5 \beta 1$ (Rohwer et al. 2008), a critical anoikis regulator in normal epithelial cells. Ligation of integrins results in the activation of many RTKs in the absence of a ligand including epidermal growth factor receptor (EGFR), insulin receptor, platelet-derived growth factor receptor (PDGFR), VEGFR2, and Met (for a review, see Streuli and Akhtar 2009). In many cases, this seems to involve the induction of a direct interaction between integrins and growth factor receptors following integrin ligation. However, this is not the case with the collaboration of $\alpha 6 \beta 4$ and Met receptor. Cells expressing only Met in the absence of $\alpha 6 \beta 4$ integrin are unable to respond to human growth factor (HGF), the ligand for Met. Interestingly, the interaction between Met and a truncated form of $\beta 4$ integrin that is unable to bind laminin is sufficient to restore HGF responses (Trusolino et al. 2001). This demonstrates that integrins can also collaborate with RTKs in an adhesion-independent manner.

Indeed, in most cases, integrins seem to function as positive regulators of growth factor receptor signaling. However, integrin $\alpha 1 \beta 1$ has a unique negative role in regulating EGFR and VEGFR2 signaling (Fig. 1). In response to adhesion to collagen, the integrin $\alpha 1$-subunit cytoplasmic tail interacts with a non-receptor protein tyrosine phosphatase TCPTP. This leads to the activation of TCPTP spatially at the membrane and results in the dephosphorylation of EGFR and VEGFR2 and thus attenuation of their signaling (Mattila et al. 2005, 2008).

Studies of transgenic animals lacking expression of $\beta 4$ integrin in the breast epithelium have highlighted the importance of the integrin-RTK co-operation in cancer initiation in vivo. Initiation and progression of breast cancer can be studied by using a mouse model of ErbB2-induced mammary carcinoma. When $\beta 4$-integrin is deleted from the mammary epithelium of these mice, the onset of tumors and their invasive growth is suppressed. This is attributable to the requirement for $\beta 4$-integrin to amplify the signaling of ErbB2 in vivo to promoter tumor progression. Even though 
ErbB2 receptor does not bind growth factors, it readily heterodimerizes with members of the ErbB-family of RTKs that are activated by growth factors (Bublil and Yarden 2007). Therefore, integrins probably function also to amplify growth-factor-induced signals in vivo. Interestingly, $\beta 4$-integrin is necessary for ErbB2-mediated tumorigenesis, as mice lacking expression of $\beta 4$-integrin in the mammary epithelium show suppressed tumor onset and invasive growth (Guo et al. 2006).

\section{Endocytosis and recycling}

Integrin endo-exocytic traffic is now widely accepted to contribute to cell migration by supporting adhesion site dynamics and the localized targeting of the adhesion receptors. Integrins are constantly endocytosed from the cell surface and are then rapidly recycled to the plasma membrane either by the short-loop small GTPase Rab4 recycling route (in the case of $\alpha v \beta 3$ ) or by the long-loop recycling via a Rab11-positive compartment (in the case of most $\beta 1$-integrins). Integrin endocytosis has been described via several entry routes including clathrin-dependent and independent pathways. These principles of integrin endo/ excocytic traffic have been review extensively and are not discussed here in detail (Jones et al. 2006; Pellinen and Ivaska 2006). However, recent work on integrin traffic is revealing the complexity of the way that integrin traffic contributes to cell motility. As is becoming obvious, the link between migration and integrin traffic is highly cellcontext-dependent, and processes supporting cell motility in the widely used, traditional, in vitro assays may indeed be totally insignificant in three-dimensional and other models that are more relevant in vivo. Small GTPases have been shown to regulate integrin traffic in part based on their distinct expression patterns. Rab21 small GTPase regulates integrin endo/exocytosis by interacting with the $\alpha$-subunit of most integrins in several different cell lines (Pellinen et al. 2006). This is important for cell migration, at least in breast and prostate cancer cells in two dimensions. In addition, Rab21 regulates cell anchorage and cytokinetic furrow formation during cell division in two dimensions (Pellinen et al. 2008). In contrast, Caswell et al. (2007) have reported that, in epithelial ovarian carcinoma cells, Rab25 interacts directly with the integrin $\beta$-subunit. Interestingly, Rab 25 regulates $\alpha 5 \beta 1$ integrin traffic spatially in extending pseudopods, resulting in increased migration on cell-derived matrix and increased invasion in threedimensional matrices, but has no effect on cell migration in two dimensions.

Endocytosis was initially considered as a mechanism for the downregulation of signaling by growth factor receptors following ligand engagement. Today, spatially regulated signaling of receptors from the endosome is well established (Mosesson et al. 2008). Recently, growth factor receptors and some other adhesion receptors have been shown to regulate integrin endocytosis and vice versa (Fig. 1). Neuropilin-1 is a transmembrane glycoprotein that functions as an adhesion receptor and a co-receptor for both pro- and anti-angiogenic factors (Olsson et al. 2006; Shimizu et al. 2000). Interestingly, neuropilin-1 seems to regulate the internalization of active $\alpha 5 \beta 1$ integrin in endothelial cells and to regulate their ability to assemble fibronectin (Valdembri et al. 2009). Recently, the expression of T-cadherin, a glycophosphatidylinositol-anchored cadherin molecule, has also been shown to suppress the internalization of $\beta 1$-integrins, whereas the stimulation of EGFR with EGF induces the internalization of $\beta 1$-integrin (Mukoyama et al. 2007). These studies demonstrate that integrin endocytosis can be governed by other cell-surface receptors. Conversely, the internalization of the junctional adhesion molecule JAM-A has recently been shown to be dependent on integrin internalization, and the chemotactic migration of neutrophils requires the co-endocytosis of both receptors (Cera et al. 2009). These examples are interesting and suggest that the cross-talk between the various receptors is also governed at the levels of endocytosis. Even though integrins and growth factor receptors have

Table 2 Integrin cross-talk with other receptor systems in endosomes (VEGFR vascular endothelial growth factor receptor, $E G F R$ epidermal growth factor receptor, $J A M-A$ junctional adhesion molecule-A)

\begin{tabular}{llll}
\hline Integrin & Other receptors & Physiological role & Reference \\
\hline$\alpha \mathrm{v} \beta 3$ & Integrin $\alpha 5 \beta 1$ & Integrin $\alpha \mathrm{v} \beta 3$ inhibits recycling of $\alpha 5 \beta 1$; reduced invasion & White et al. 2007 \\
$\alpha \mathrm{v} \beta 3$ & EGFR & Integrin $\alpha \mathrm{v} \beta 3$ inhibits recycling of EGFR; reduced invasion & Caswell et al. 2008 \\
$\alpha 5 \beta 1$ & Neuroplilin-1 & Neuropilin-1 induces $\alpha 5 \beta 1$ endocytosis & Valdembri et al. 2009 \\
$\beta 1$ & T-cadherin & T-cadherin inhibits $\beta$ 1-integrin endocytosis & Mukoyama et al. 2007 \\
$\beta 1$ & JAM-A & JAM-A internalization depends on $\beta 1$-integrin endocytosis; neutrophil chemotaxis & Cera et al. 2009 \\
$\alpha \mathrm{V} \beta 3$ & VEGFR1 & VEGFR1 stimulates recycling of $\alpha \mathrm{v} \beta 3$; fibronectin assembly & Jones et al. 2009 \\
$\alpha \mathrm{V} \beta 3, \alpha \mathrm{V} \beta 5$ & VEGFR2 & Integrin inhibition results in increased VEGFR2 recycling and angiogenesis & Reynolds et al. 2009 \\
\hline
\end{tabular}


been shown to co-cluster and form complexes, whether they can also be co-endocytosed together in a liganddependent or ligand-independent way remains unclear.

More progress has been made in understanding the recycling of integrins and growth factor receptors and the cross-talk between the various integrins. As is becoming apparent, the trafficking of diverse cargo along distinct endocytic pathways results in functional interdependence whereby one pathway influences the other. Integrin $\alpha \mathrm{v} \beta 3$ traffics through the Rab4-positive rapid-recycling pathway. Interestingly, this regulates the recycling of another RGDbinding receptor $\alpha 5 \beta 1$ integrin. When $\alpha \mathrm{v} \beta 3$ is functional and rapidly trafficking, $\alpha 5 \beta 1$ integrin is recycled less, and cells migrate persistently in two dimensions (Caswell et al. 2008; White et al. 2007). However, the inhibition of $\alpha \mathrm{v} \beta 3$ with the small molecule antagonist cilengitide results in an increased recycling of $\alpha 5 \beta 1$. This results in random motility in two dimensions but an increased invasiveness in three dimensions (White et al. 2007). Interestingly, $\alpha 5 \beta 1$ forms a complex with EGFR and Rab GTPase effector Rabcoupling protein in the recycling endosomal compartment. Inhibition of $\alpha v \beta 3$ also results in increased recycling of EGFR to the plasma membrane resulting in increased invasion and activation of the Akt pathway (Caswell et al. 2008). EGFR has been shown to recycle when engaged with lower affinity ligands such as TGF $\alpha$ (Ebner and Derynck 1991; Waterman and Yarden 2001). However, recent data suggest that alterations in other cellular signaling pathways result in the recycling of other growth factor receptors. PDFGR $\beta$ does not recycle normally. However, it has been shown to recycle rapidly if it becomes hyperphosphorylated upon loss of its negative regulator TCPTP protein tyrosine phosphatase (Hellberg et al. 2009; Karlsson et al. 2006). This has not yet been linked to integrin traffic, but since integrin adhesion regulates TCPTP activity (Mattila et al. 2005), and since PDGFR $\beta$ can co-cluster and be activated without a ligand by the integrins (Schneller et al. 1997), integrin traffic might also regulate PDGFR $\beta$ function. In endothelial cells, intimate cross-talk seems to occur between the trafficking of $\alpha \mathrm{v} \beta 3$ integrin and VEGFR1 and -2 receptors. VEGFR1 activates the recycling of $\alpha v \beta 3$ integrin from the Rab4-positive compartment and is involved in regulating fibronectin polymerization (Jones et al. 2009). Conversely, inhibition of $\alpha \mathrm{v} \beta 3$ with cilengitide alters the recycling of VEGFR2, thus promoting angiogenesis (Reynolds et al. 2009). This is unexpected as integrin inhibitors are currently undergoing clinical trials as anti-angiogenic agents. Thus, a new platform for integrin and growth factors receptor co-operation and cross-talk is emerging at the endosomal compartment (summarized in Table 2), and future findings in this area are likely to provide important new insights into invasion, transformation, and the regulation of angiogenesis.

\section{Concluding remarks}

The emerging information about growth factor and cell adhesion receptors has unveiled a multiplicity of mechanisms regarding the way that the receptor systems work together. Integrin binding to ECM proteins and growth factor binding to their own receptors regulate many common signaling pathways. Integrins may directly bind to some growth factors and, in the case of TGF- $\beta$, activate them (Munger et al. 1999). Furthermore, activated integrins form receptor clusters that also contain growth factor receptors. In these protein complexes, integrins are required for the formation of a platform in which growth factor receptors can properly interact with downstream signaling partners (Yamada and Even-Ram 2002). Interestingly, within the integrin-organized complexes, growth factor receptors can be activated even without ligands. The most recent observations have revealed a new level in the interplay between integrins and growth factor receptors. Previously, both receptor types were known to be internalized and recycled back to the cell surface. However, current reports indicate that integrins orchestrate the intracellular trafficking of growth factor receptors (Caswell and Norman 2008; Caswell et al. 2008).

This new information might help to explain the contradictory results that have generated debate during the past few years with regard to integrin function. Especially in the cases of $\alpha \mathrm{V}$ integrins and $\alpha 2 \beta 1$ integrin, results obtained in the knockout phenotypes have been in conflict with those from experiments involving the use of integrin inhibitors (Hynes 2002; Zhang et al. 2008). Recent observations indicate that the lack of integrins affects the levels of growth factor receptors on the cell surface (Zhang et al. 2008). Furthermore, integrin inhibitors not only might block integrin binding to ligands, but may also affect signaling by growth factor receptors (Reynolds et al. 2009). Thus, the new data stress the role of integrins as integral parts of the cellular signaling machinery. Furthermore, the direct role of specific integrins must be reconsidered in certain biological processes, such as angiogenesis.

Acknowledgements The authors thank Mr. Timo Kattelus for the illustrations.

Open Access This article is distributed under the terms of the Creative Commons Attribution Noncommercial License which permits any noncommercial use, distribution, and reproduction in any medium, provided the original author(s) and source are credited.

\section{References}

Arnaout MA, Goodman SL, Xiong JP (2007) Structure and mechanics of integrin-based cell adhesion. Curr Opin Cell Biol 19:495-507 
Asano Y, Ihn H, Yamane K, Jinnin M, Mimura Y, Tamaki K (2005) Increased expression of integrin alpha(v)beta3 contributes to the establishment of autocrine TGF-beta signaling in scleroderma fibroblasts. J Immunol 175:7708-7718

Bader BL, Rayburn H, Crowley D, Hynes RO (1998) Extensive vasculogenesis, angiogenesis, and organogenesis precede lethality in mice lacking all alpha $\mathrm{V}$ integrins. Cell 95:507-519

Brooks PC, Clark RA, Cheresh DA (1994) Requirement of vascular integrin alpha $\mathrm{V}$ beta 3 for angiogenesis. Science 264:569-571

Bublil EM, Yarden Y (2007) The EGF receptor family: spearheading a merger of signaling and therapeutics. Curr Opin Cell Biol 19:124-134

Cambi A, Joosten B, Koopman M, Lange F de, Beeren I, Torensma R, Fransen JA, Garcia-Parajo M, Leeuwen FN van, Figdor CG (2006) Organization of the integrin LFA-1 in nanoclusters regulates its activity. Mol Biol Cell 17:4270-4281

Cambier S, Gline S, Mu D, Collins R, Araya J, Dolganov G, Einheber S, Boudreau N, Nishimura SL (2005) Integrin alpha(V)beta8mediated activation of transforming growth factor-beta by perivascular astrocytes: an angiogenic control switch. Am J Pathol 166:1883-1894

Carlson TR, Feng Y, Maisonpierre PC, Mrksich M, Morla AO (2001) Direct cell adhesion to the angiopoietins mediated by integrins. J Biol Chem 276:26516-26525

Caswell P, Norman J (2008) Endocytic transport of integrins during cell migration and invasion. Trends Cell Biol 18:257-263

Caswell PT, Spence HJ, Parsons M, White DP, Clark K, Cheng KW, Mills GB, Humphries MJ, Messent AJ, Anderson KI, McCaffrey MW, Ozanne BW, Norman JC (2007) Rab25 associates with alpha5betal integrin to promote invasive migration in $3 \mathrm{D}$ microenvironments. Dev Cell 13:496-510

Caswell PT, Chan M, Lindsay AJ, McCaffrey MW, Boettiger D, Norman JC (2008) Rab-coupling protein coordinates recycling of alpha5beta1 integrin and EGFR1 to promote cell migration in 3D microenvironments. J Cell Biol 183:143-155

Cera MR, Fabbri M, Molendini C, Corada M, Orsenigo F, Rehberg M, Reichel CA, Krombach F, Pardi R, Dejana E (2009) JAM-A promotes neutrophil chemotaxis by controlling integrin internalization and recycling. J Cell Sci 122:268-277

Connors WL, Jokinen J, White DJ, Puranen JS, Kankaanpaa P, Upla P, Tulla M, Johnson MS, Heino J (2007) Two synergistic activation mechanisms of alpha2beta1 integrin-mediated collagen binding. J Biol Chem 282:14675-14683

Crawford SE, Stellmach V, Murphy-Ullrich JE, Ribeiro SM, Lawler J, Hynes RO, Boivin GP, Bouck N (1998) Thrombospondin-1 is a major activator of TGF-beta1 in vivo. Cell 93:1159-1170

Danen EH, Yamada KM (2001) Fibronectin, integrins, and growth control. J Cell Physiol 189:1-13

DiPersio CM, Hodivala-Dilke KM, Jaenisch R, Kreidberg JA, Hynes RO (1997) Alpha3beta1 integrin is required for normal development of the epidermal basement membrane. J Cell Biol 137:729 742

Douma S, Van Laar T, Zevenhoven J, Meuwissen R, Van Garderen E, Peeper DS (2004) Suppression of anoikis and induction of metastasis by the neurotrophic receptor TrkB. Nature 430:1034-1039

Dowling J, Yu QC, Fuchs E (1996) Beta4 integrin is required for hemidesmosome formation, cell adhesion and cell survival. J Cell Biol 134:559-572

Ebner R, Derynck R (1991) Epidermal growth factor and transforming growth factor-alpha: differential intracellular routing and processing of ligand-receptor complexes. Cell Regul 2:599-612

Evans R, Patzak I, Svensson L, De Filippo K, Jones K, McDowall A, Hogg N (2009) Integrins in immunity. J Cell Sci 122:215-225

Frisch SM, Francis H (1994) Disruption of epithelial cell-matrix interactions induces apoptosis. J Cell Biol 124:619-626
Frisch SM, Ruoslahti E (1997) Integrins and anoikis. Curr Opin Cell Biol 9:701-706

Guo W, Pylayeva Y, Pepe A, Yoshioka T, Muller WJ, Inghirami G, Giancotti FG (2006) Beta 4 integrin amplifies ErbB2 signaling to promote mammary tumorigenesis. Cell 126:489-502

Hakkinen L, Koivisto L, Gardner H, Saarialho-Kere U, Carroll JM, Lakso M, Rauvala H, Laato M, Heino J, Larjava H (2004) Increased expression of beta6-integrin in skin leads to spontaneous development of chronic wounds. Am J Pathol 164:229 242

Hayashi YK, Chou FL, Engvall E, Ogawa M, Matsuda C, Hirabayashi S, Yokochi K, Ziober BL, Kramer RH, Kaufman SJ, Ozawa E, Goto Y, Nonaka I, Tsukahara T, Wang JZ, Hoffman EP, Arahata $\mathrm{K}$ (1998) Mutations in the integrin alpha7 gene cause congenital myopathy. Nat Genet 19:94-97

Heino J (2007) The collagen family members as cell adhesion proteins. Bioessays 29:1001-1010

Hellberg C, Schmees C, Karlsson S, Ahgren A, Heldin CH (2009) Activation of protein kinase $\mathrm{C}\{$ alpha $\}$ is necessary for sorting the PDGF \{beta\}-receptor to Rab4a-dependent recycling. Mol Biol Cell 20:2856-2863

Huang XZ, Wu JF, Ferrando R, Lee JH, Wang YL, Farese RV Jr, Sheppard D (2000) Fatal bilateral chylothorax in mice lacking the integrin alpha9beta1. Mol Cell Biol 20:5208-5215

Hutchings H, Ortega N, Plouet J (2003) Extracellular matrix-bound vascular endothelial growth factor promotes endothelial cell adhesion, migration, and survival through integrin ligation. FASEB J 17:1520-1522

Hynes RO (2002) Integrins: bidirectional, allosteric signaling machines Cell 110:673-687

Ivaska J, Bosca L, Parker PJ (2003) PKCepsilon is a permissive link in integrin-dependent IFN-gamma signalling that facilitates JAK phosphorylation of STAT1. Nat Cell Biol 5:363-369

Johnson MS, Lu N, Denessiouk K, Heino J, Gullberg D (2009) Integrins during evolution: evolutionary trees and model organisms. Biochim Biophys Acta 1788:779-789

Jones MC, Caswell PT, Norman JC (2006) Endocytic recycling pathways: emerging regulators of cell migration. Curr Opin Cell Biol 18:549-557

Jones MC, Caswell PT, Moran-Jones K, Roberts M, Barry ST, Gampel A, Mellor H, Norman JC (2009) VEGFR1 (Flt1) regulates Rab4 recycling to control fibronectin polymerization and endothelial vessel branching. Traffic 10:754-766

Karlsson S, Kowanetz K, Sandin A, Persson C, Ostman A, Heldin $\mathrm{CH}$, Hellberg C (2006) Loss of T-cell protein tyrosine phosphatase induces recycling of the platelet-derived growth factor (PDGF) beta-receptor but not the PDGF alpha-receptor. Mol Biol Cell $17: 4846-4855$

Kim M, Carman CV, Yang W, Salas A, Springer TA (2004) The primacy of affinity over clustering in regulation of adhesiveness of the integrin \{alpha\} $\{$ \{beta\}2. J Cell Biol 167:1241-1253

Kreidberg JA, Donovan MJ, Goldstein SL, Rennke H, Shepherd K, Jones RC, Jaenisch R (1996) Alpha 3 beta 1 integrin has a crucial role in kidney and lung organogenesis. Development 122:35373547

Legate KR, Fassler R (2009) Mechanisms that regulate adaptor binding to beta-integrin cytoplasmic tails. J Cell Sci 122:187-198

Legate KR, Wickstrom SA, Fassler R (2009) Genetic and cell biological analysis of integrin outside-in signaling. Genes Dev 23:397-418

Liotta LA, Kohn E (2004) Anoikis: cancer and the homeless cell. Nature 430:973-974

Littlewood Evans A, Muller U (2000) Stereocilia defects in the sensory hair cells of the inner ear in mice deficient in integrin alpha8beta1. Nat Genet 24:424-428 
Lu M, Munger JS, Steadele M, Busald C, Tellier M, Schnapp LM (2002) Integrin alpha8beta1 mediates adhesion to LAP-TGFbeta1. J Cell Sci 115:4641-4648

Luo BH, Carman CV, Springer TA (2007) Structural basis of integrin regulation and signaling. Annu Rev Immunol 25:619-647

Ma LJ, Yang H, Gaspert A, Carlesso G, Barty MM, Davidson JM, Sheppard D, Fogo AB (2003) Transforming growth factorbeta-dependent and -independent pathways of induction of tubulointerstitial fibrosis in beta6(-/-) mice. Am J Pathol 163: $1261-1273$

Mainiero F, Murgia C, Wary KK, Curatola AM, Pepe A, Blumemberg M, Westwick JK, Der CJ, Giancotti FG (1997) The coupling of alpha6beta4 integrin to Ras-MAP kinase pathways mediated by Shc controls keratinocyte proliferation. EMBO J 16:2365-2375

Mattila E, Pellinen T, Nevo J, Vuoriluoto K, Arjonen A, Ivaska J (2005) Negative regulation of EGFR signalling through integrinalpha1beta1-mediated activation of protein tyrosine phosphatase TCPTP. Nat Cell Biol 7:78-85

Mattila E, Auvinen K, Salmi M, Ivaska J (2008) The protein tyrosine phosphatase TCPTP controls VEGFR2 signalling. J Cell Sci 121:3570-3580

Mayer U, Saher G, Fassler R, Bornemann A, Echtermeyer F, Mark H von der, Miosge N, Poschl E, Mark K von der (1997) Absence of integrin alpha 7 causes a novel form of muscular dystrophy. Nat Genet 17:318-323

Michishita M, Videm V, Arnaout MA (1993) A novel divalent cationbinding site in the A domain of the beta 2 integrin CR3 (CD11b/ CD18) is essential for ligand binding. Cell 72:857-867

Miyamoto S, Teramoto H, Coso OA, Gutkind JS, Burbelo PD, Akiyama SK, Yamada KM (1995) Integrin function: molecular hierarchies of cytoskeletal and signaling molecules. J Cell Biol 131:791-805

Mori S, Wu CY, Yamaji S, Saegusa J, Shi B, Ma Z, Kuwabara Y, Lam KS, Isseroff RR, Takada YK, Takada Y (2008) Direct binding of integrin alphaVbeta3 to FGF1 plays a role in FGF1 signaling. J Biol Chem 283:18066-18075

Moser M, Legate KR, Zent R, Fassler R (2009) The tail of integrins, talin, and kindlins. Science 324:895-899

Mosesson Y, Mills GB, Yarden Y (2008) Derailed endocytosis: an emerging feature of cancer. Nat Rev Cancer 8:835-850

Mu D, Cambier S, Fjellbirkeland L, Baron JL, Munger JS, Kawakatsu H, Sheppard D, Broaddus VC, Nishimura SL (2002) The integrin alpha(V)beta8 mediates epithelial homeostasis through MT1MMP-dependent activation of TGF-beta1. J Cell Biol 157:493507

Mukoyama Y, Utani A, Matsui S, Zhou S, Miyachi Y, Matsuyoshi N (2007) T-cadherin enhances cell-matrix adhesiveness by regulating betal integrin trafficking in cutaneous squamous carcinoma cells. Genes Cells 12:787-796

Muller U, Wang D, Denda S, Meneses JJ, Pedersen RA, Reichardt LF (1997) Integrin alpha8beta1 is critically important for epithelialmesenchymal interactions during kidney morphogenesis. Cell 88:603-613

Munger JS, Harpel JG, Giancotti FG, Rifkin DB (1998) Interactions between growth factors and integrins: latent forms of transforming growth factor-beta are ligands for the integrin alphaVbeta1. Mol Biol Cell 9:2627-2638

Munger JS, Huang X, Kawakatsu H, Griffiths MJ, Dalton SL, Wu J, Pittet JF, Kaminski N, Garat C, Matthay MA, Rifkin DB, Sheppard D (1999) The integrin alpha V beta 6 binds and activates latent TGF beta 1: a mechanism for regulating pulmonary inflammation and fibrosis. Cell 96:319-328

Olsson AK, Dimberg A, Kreuger J, Claesson-Welsh L (2006) VEGF receptor signalling - in control of vascular function. Nat Rev Mol Cell Biol 7:359-371
Parsons MJ, Patel P, Brat DJ, Colbert L, Vertino PM (2009) Silencing of TMS1/ASC promotes resistance to anoikis in breast epithelial cells. Cancer Res 69:1706-1711

Pellinen T, Ivaska J (2006) Integrin traffic. J Cell Sci 119:3723-3731

Pellinen T, Arjonen A, Vuoriluoto K, Kallio K, Fransen JA, Ivaska J (2006) Small GTPase Rab21 regulates cell adhesion and controls endosomal traffic of beta1-integrins. J Cell Biol 173:767-780

Pellinen T, Tuomi S, Arjonen A, Wolf M, Edgren H, Meyer H, Grosse R, Kitzing T, Rantala JK, Kallioniemi O, Fassler R, Kallio M, Ivaska J (2008) Integrin trafficking regulated by Rab21 is necessary for cytokinesis. Dev Cell 15:371-385

Reynolds LE, Wyder L, Lively JC, Taverna D, Robinson SD, Huang X, Sheppard D, Hynes RO, Hodivala-Dilke KM (2002) Enhanced pathological angiogenesis in mice lacking beta3 integrin or beta 3 and beta5 integrins. Nat Med 8:27-34

Reynolds AR, Hart IR, Watson AR, Welti JC, Silva RG, Robinson SD, Da Violante G, Gourlaouen M, Salih M, Jones MC, Jones DT, Saunders G, Kostourou V, Perron-Sierra F, Norman JC, Tucker GC, Hodivala-Dilke KM (2009) Stimulation of tumor growth and angiogenesis by low concentrations of RGD-mimetic integrin inhibitors. Nat Med 15:392-400

Rohwer N, Welzel M, Daskalow K, Pfander D, Wiedenmann B, Detjen K, Cramer T (2008) Hypoxia-inducible factor 1alpha mediates anoikis resistance via suppression of alpha5 integrin. Cancer Res 68:10113-10120

Ruoslahti E (1999) Fibronectin and its integrin receptors in cancer. Adv Cancer Res 76:1-20

Sato Y, Rifkin DB (1989) Inhibition of endothelial cell movement by pericytes and smooth muscle cells: activation of a latent transforming growth factor-beta 1-like molecule by plasmin during co-culture. J Cell Biol 109:309-315

Schneller M, Vuori K, Ruoslahti E (1997) AlphaVbeta3 integrin associates with activated insulin and PDGFbeta receptors and potentiates the biological activity of PDGF. EMBO J 16:5600 5607

Schwartz MA, Assoian RK (2001) Integrins and cell proliferation: regulation of cyclin-dependent kinases via cytoplasmic signaling pathways. J Cell Sci 114:2553-2560

Shaw LM, Rabinovitz I, Wang HH, Toker A, Mercurio AM (1997) Activation of phosphoinositide 3-OH kinase by the alpha6beta4 integrin promotes carcinoma invasion. Cell 91:949-960

Shimizu M, Murakami Y, Suto F, Fujisawa H (2000) Determination of cell adhesion sites of neuropilin-1. J Cell Biol 148:1283-1293

Simpson CD, Anyiwe K, Schimmer AD (2008) Anoikis resistance and tumor metastasis. Cancer Lett 272:177-185

Staniszewska I, Sariyer IK, Lecht S, Brown MC, Walsh EM, Tuszynski GP, Safak M, Lazarovici P, Marcinkiewicz C (2008) Integrin alpha9 beta1 is a receptor for nerve growth factor and other neurotrophins. J Cell Sci 121:504-513

Streuli CH, Akhtar N (2009) Signal co-operation between integrins and other receptor systems. Biochem J 418:491-506

Suzuki K, Okuno T, Yamamoto M, Pasterkamp RJ, Takegahara N, Takamatsu H, Kitao T, Takagi J, Rennert PD, Kolodkin AL, Kumanogoh A, Kikutani H (2007) Semaphorin 7A initiates Tcell-mediated inflammatory responses through alphalbetal integrin. Nature 446:680-684

Tadokoro S, Shattil SJ, Eto K, Tai V, Liddington RC, Pereda JM de, Ginsberg MH, Calderwood DA (2003) Talin binding to integrin beta tails: a final common step in integrin activation. Science 302:103-106

Trusolino L, Bertotti A, Comoglio PM (2001) A signaling adapter function for alpha6beta4 integrin in the control of HGFdependent invasive growth. Cell 107:643-654

Valdembri D, Caswell PT, Anderson KI, Schwarz JP, Konig I, Astanina E, Caccavari F, Norman JC, Humphries MJ, Bussolino F, Serini G (2009) Neuropilin-1/GIPC1 signaling regulates 
alpha5beta1 integrin traffic and function in endothelial cells. PLoS Biol 7:e25

Wang B, Dolinski BM, Kikuchi N, Leone DR, Peters MG, Weinreb PH, Violette SM, Bissell DM (2007) Role of alphaVbeta6 integrin in acute biliary fibrosis. Hepatology 46:1404-1412

Wang Y, Roche O, Yan MS, Finak G, Evans AJ, Metcalf JL, Hast BE, Hanna SC, Wondergem B, Furge KA, Irwin MS, Kim WY, Teh BT, Grinstein S, Park M, Marsden PA, Ohh M (2009) Regulation of endocytosis via the oxygen-sensing pathway. Nat Med 15:319-324

Wary KK, Mainiero F, Isakoff SJ, Marcantonio EE, Giancotti FG (1996) The adaptor protein Shc couples a class of integrins to the control of cell cycle progression. Cell 87:733-743

Wary KK, Mariotti A, Zurzolo C, Giancotti FG (1998) A requirement for caveolin-1 and associated kinase Fyn in integrin signaling and anchorage-dependent cell growth. Cell 94:625-634

Waterman H, Yarden Y (2001) Molecular mechanisms underlying endocytosis and sorting of ErbB receptor tyrosine kinases. FEBS Lett 490:142-152

White DP, Caswell PT, Norman JC (2007) AlphaVbeta3 and alpha5betal integrin recycling pathways dictate downstream Rho kinase signaling to regulate persistent cell migration. J Cell Biol 177:515-525

Vlahakis NE, Young BA, Atakilit A, Sheppard D (2005) The lymphangiogenic vascular endothelial growth factors VEGF-C and $-\mathrm{D}$ are ligands for the integrin alpha9beta1. J Biol Chem 280:4544-4552
Vlahakis NE, Young BA, Atakilit A, Hawkridge AE, Issaka RB, Boudreau N, Sheppard D (2007) Integrin alpha9betal directly binds to vascular endothelial growth factor (VEGF)-A and contributes to VEGF-A-induced angiogenesis. J Biol Chem 282:15187-15196

Yamada KM, Even-Ram S (2002) Integrin regulation of growth factor receptors. Nat Cell Biol 4:E75-E76

Yang JT, Rayburn H, Hynes RO (1993) Embryonic mesodermal defects in alpha 5 integrin-deficient mice. Development 119:1093-1105

Yang JT, Rayburn H, Hynes RO (1995) Cell adhesion events mediated by alpha 4 integrins are essential in placental and cardiac development. Development 121:549-560

Yu Q, Stamenkovic I (2000) Cell surface-localized matrix metalloproteinase-9 proteolytically activates TGF-beta and promotes tumor invasion and angiogenesis. Genes Dev 14:163-176

Zhang Z, Ramirez NE, Yankeelov TE, Li Z, Ford LE, Qi Y, Pozzi A, Zutter MM (2008) Alpha2beta1 integrin expression in the tumor microenvironment enhances tumor angiogenesis in a tumor cellspecific manner. Blood 111:1980-1988

Zhu J, Motejlek K, Wang D, Zang K, Schmidt A, Reichardt LF (2002) Beta8 integrins are required for vascular morphogenesis in mouse embryos. Development 129:2891-2903

Zhu J, Luo BH, Xiao T, Zhang C, Nishida N, Springer TA (2008) Structure of a complete integrin ectodomain in a physiologic resting state and activation and deactivation by applied forces. Mol Cell 32:849-861 